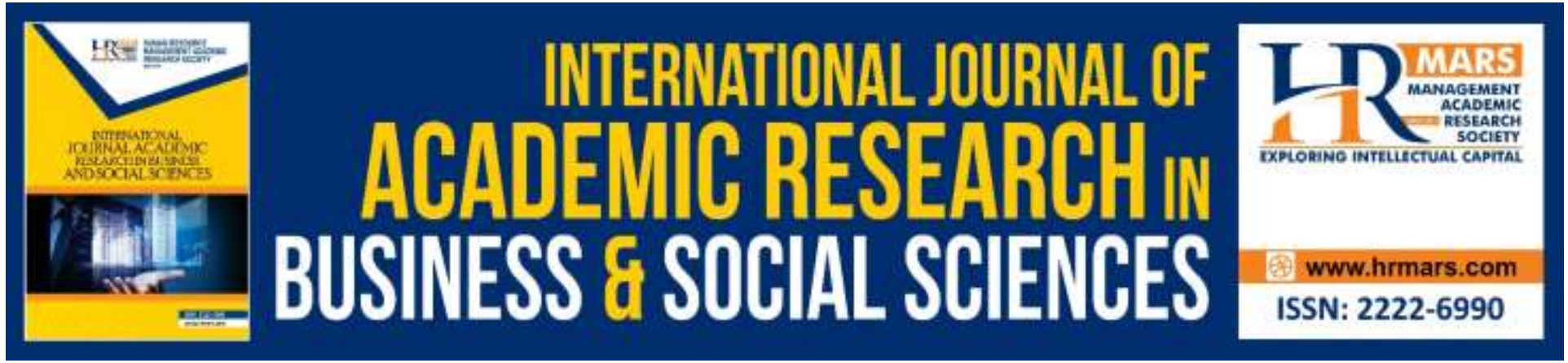

\title{
Mobile App for Learning Economics Terminologies
}

\section{Wan Normeza Wan Zakaria, Hafiza Abas, Maslin Masrom, Raihana Mohdali and Nik Nadzirah Nik Mohamed}

To Link this Article: http://dx.doi.org/10.6007/IJARBSS/v9-i10/6477

DOI:10.6007/IJARBSS/v9-i10/6477

Received: 14 September 2019, Revised: 01 October 2019, Accepted: 15 October 2019

Published Online: 30 October 2019

In-Text Citation: (Zakaria, Abas, Masrom, Mohdali, \& Mohamed, 2019)

To Cite this Article: Zakaria, W. N. W., Abas, H., Masrom, M., Mohdali, R., \& Mohamed, N. N. N. (2019). Mobile App for Learning Economics Terminologies. International Journal of Academic Research in Business and Social Sciences, 9(10), 191-202.

\section{Copyright: (C) 2019 The Author(s)}

Published by Human Resource Management Academic Research Society (www.hrmars.com)

This article is published under the Creative Commons Attribution (CC BY 4.0) license. Anyone may reproduce, distribute, translate and create derivative works of this article (for both commercial and non-commercial purposes), subject to full attribution to the original publication and authors. The full terms of this license may be seen at: http://creativecommons.org/licences/by/4.0/legalcode

\section{Vol. 9, No. 10, 2019, Pg. 191 - 202}

Full Terms \& Conditions of access and use can be found at http://hrmars.com/index.php/pages/detail/publication-ethics 


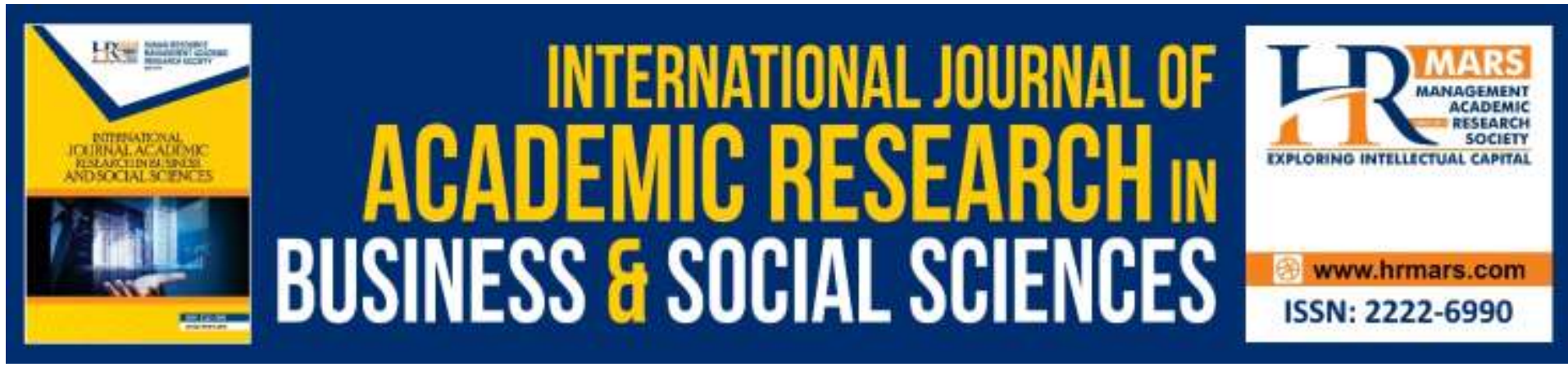

\title{
Mobile App for Learning Economics Terminologies
}

\author{
Wan Normeza Wan Zakaria, Hafiza Abas, Maslin Masrom, \\ Raihana Mohdali and Nik Nadzirah Nik Mohamed \\ Razak Faculty of Technology and Informatics, Universiti Teknologi Malaysia, Kuala Lumpur, \\ Malaysia \\ E-mail:normeza.kl@utm.my,hafiza.kl@utm.my,maslin.kl@utm.my,raihana.kl@utm.my, \\ nadzirah.kl@utm.my
}

\begin{abstract}
The use of the educational mobile app in teaching and learning is getting popular nowadays due to improvement in technology, better accessibility, users' acceptance and affordances of mobile devices. This paper discusses the conceptual design of Economics mobile app for learning economics terminologies. The app is designed for ubiquitous self-learning based on cognitive theories, which are information processing theory and cognitive theory in multimedia learning. The users are secondary school students in Malaysia. A qualitative study is adopted for data collection where interviews will be conducted with Economics teachers to identify the list of economic terminologies to be included in the app and also to explore the effective methods of delivering the meaning of those terminologies. The app is aimed to aid students to build understanding and knowledge of the economics terminologies, process the information for long term retention and increase their interest in Economics subject to improve economic literacy. The details of the app are explained in this paper.
\end{abstract}

Keywords: Economics Terminologies, Mobile App, Cognitive Theories, Self-Learning, Economics Literacy

\section{Introduction}

Today, with the advancement of mobile technology, better access to the internet, together with the affordability of having mobile devices and increased interest in online surfing among students. It has given opportunities for educators to utilize this technology as a mobile learning tool. One method that is increasing in popularity is an educational mobile app.

A mobile application or most commonly referred to as an app is a type of application software designed to run on a mobile device, such as a smartphone or tablet computer. These devices have a large amount of computing power, portable, internet accessible and enable efficient communication make them great potential learning tools for both classroom learning and self-learning (Sung et al., 2016). These devices become necessary items for most people nowadays including students. For that purpose, various mobile apps have been designed and 
developed to be run on these devices. This approach makes learning faster, easier, and more attractive by creating a student-centered learning environment and by offering newer methods of teaching (Aggarwal, 2017).

The mobile app offers a lot of benefits such as interactive learning, 24/7 availability, portability, individually focused learning and leisure hour utilization. Besides, many studies show that mobile app brings a significant positive impact on learning performance as it improves attitudes toward the usage of the mobile learning system (Hao et al., 2019; Jou et al., 2016) and improve motivation to learn (Li et al., 2018).

Previous studies show that many researchers have utilized these ubiquitous technologies to support classroom learning. Cheong et al. (2012) designed myVote, a mobile-app-based collaborative learning system. This app is a versatile system which can be adapted for education in general and also non-educational settings, such as business-like environments. Herodotu et al. (2018) designed citizen science tools for inquiry learning that is named as nQuire. This toolkit is a set of web-based and mobile tools scaffolding the creation of online citizen science investigations.

Further, some researchers developed an app to be utilized on tablets and smartphones for special needs students such as Sierra \& Togores (2012), Daud \& Abas (2013), Ahmad \& Shahid (2015) and Stathopoulou et.al (2019). Besides, a mobile app was also designed specifically for learning vocabularies (Deng \& Trainin, 2015; Moo Chan et al., 2017; Wang, 2017; Kuimova, 2018). This app is designed to teach students various words of specific languages. Many apps are also available for Economics students internationally such as Khan Academy (Kelly, 2016).

\section{Background of the Study}

Economics education is one of the factors that contribute to economics literacy (Varum et al., 2014). Students attain economic literacy if they can apply basic economic concepts years later, in situations relevant to their lives and different from those encountered in the classroom (Salemi, 2005). Economics literacy is essential to every individual in society because everyone will become consumers, workers, producers, employers, investors, exporters, importer and policymakers in society (Johnson, 2013). Some gain economics literacy through formal learning and some through experience.

In Malaysia, Economics is taught formally through the teaching of Economics subject. This subject is introduced to the students during secondary educations. According to Salemi (2005), at the foundation course, students should attain a deeper understanding and working knowledge of a shortlist of economics concepts. These economics concepts are terminologies that have specific meanings.

Due to many unfamiliar, the economics terminologies and abstract nature of the content, many students perceive Economics as a difficult subject (Backhouse, 2012), (Ro' ufah Inayati, et al. 2019). Many teaching and learning approaches have been proposed to make teaching and learning Economics interesting and improve students' performance including the use of apps (Cochran et al., 2014). Yet, Economics educational app which is specifically designed for 
school students in Malaysia is still not much available. To fill in this gap, this paper proposes the conceptual design of Economics mobile app for secondary school students in Malaysia.

According to Camilleri \& Camilleri (2019) and Kearney et al. (2012) a good and effective educational app should focus on pedagogical aspects besides emphasizing on technological elements. Thus, the focus of this paper is on pedagogical approaches of mobile apps to aid students build understanding and knowledge of the economics terminologies, process the information for long term retention and increase their interest in Economics subject to improve economic literacy.

\section{Literature Review \\ Economics Terminologies}

Economics terminologies are specific words, group of words or vocabularies that have specific meanings which explain about the economics concepts. Economics concepts are abstract ideas that form the foundation for the body of economics knowledge. Scarcity, demand, supply, market equilibrium and economies of scale are some examples of economics terminologies. Students are introduced to various economics terminologies at every level of the Economics curriculum. To be economically literate, students should acquire a deeper understanding of these terminologies (Salemi, 2005).

\section{Mobile App for Teaching and Learning the Meaning of Terminologies}

Economics terminologies are words which have a specific meaning. Many apps have been designed for teaching and learning the meaning of words. For instance, Wang (2017) designed a student-centered mobile app for learning English words for Taiwanese college students. The app has three main features that are a list of English words, sample sentences using the word in English and the translated sentence in Chinese. In language learning, the learning of the meaning of words is known as vocabulary learning. Wang (2017) found that his studentscentered app gives freedom to students to choose where and when to learn, improved students' motivation to learn English vocabulary and develop students' confidence in language learning. Moo Chan et al. (2017) on the other hand, designed an interactive educational app to assist the learning of the Mayan language. They incorporated text, image and audio, with vocabulary, grammar and pronunciation activities.

Deng \& Trainin (2015) proposed four vocabulary-learning strategies by using mobile app which are dictionary use (i.e learning words by looking up definitions, pronunciations, etymology and synonyms or antonyms of words), phonological analysis (i.e., learning words by analyzing the sound parts), morphological analysis (i.e., learning word meanings by analyzing the componential word parts), and contextual analysis (i.e., learning word meanings by referring to learning context). According to them mobile app can be used to enhance vocabulary acquisition.

These studies show that mobile apps are good for teaching and learning the meaning of words. The app can be designed for various learning approaches such as self-learning and interactive learning. The content of the app should contain text, image and audio. Besides, in teaching and learning the meaning of the word, there are choices of strategies that can be 
imposed in an app such as dictionary use, phonological analysis, morphological analysis and contextual analysis.

\section{Underpinning Theories}

The design of this Economics app is based on two cognitive theories, which are Information processing theory and cognitive theory in multimedia learning.

\section{Information Processing Theory}

This is a cognitive theory of learning that explains the processing, storage and retrieval of information in the memory (Slavin, 2019). The information processing model depicts that human memory comprises three memory stores which are sensory memory, short term or working memory and long term that comes to our mind and transferring information from one store to memory. The processes of receiving and selecting information in another store are known as cognitive processes (Eggen and Kauchak, 2013).

Information from the environment will be received and selected by sensory memory. According to Kelley and Clausen-Grace (2010) text features such as titles, table of contents, sub-titles, bold words, sidebars, pictures and captions, diagrams, charts and graphs can be very helpful in assisting students to identify and select main information from the text.

Then, the selected information will be kept active for a few seconds in working memory by rehearsing or repeating it in the mind. This process is known as maintenance rehearsal (Woolfolk, 2013). It occurs when students repeat the information over and over, read over the material a few times, rewrite the sentences or redraw the diagrams and graphs several times (Blerkom, 2009).

The next process is transferring information from working memory to long term memory for long term storage. Processes involve are elaboration and organization. Elaboration is the process of connecting the information that we want to remember with existing information (Woolfolk, 2013). It includes among others summarizing, paraphrasing, note making, mnemonics, and asking and answering questions. The organization on the other hand, is the process of arranging the information in an ordered and structured manner. Making charts, mapping concepts, making flowcharts, creating tables, classifying information, finding similarities, representing information in charts, tables and diagrams are among organization strategies (Tay, 2013).

\section{Cognitive Theory in Multimedia Learning}

Mayer's cognitive theory of multimedia learning (CTML) is a popular framework for the instructional design of multimedia applications such as apps (Mayer, 2014). CTML is based on an integration of Sweller's cognitive load theory (Sweller, 1994) and Baddeley's working memory model (Baddeley, 1986). These theories explain how that information (text, graphics, audio, video and animation) should be presented and interact with the limitation of users' working memory. The CTML specifies five cognitive processes in multimedia learning: (i) Selecting relevant words from the presented text or narration; (ii) Selecting relevant images from the presented graphics; (iii) Organizing the selected words into a coherent verbal 
representation; (iv) Organizing selected images into a coherent pictorial representation; and (v) Integrating the pictorial and verbal representations and prior knowledge.

CTML proposes that there are separate channels for processing auditory and visual information. Each channel has a limited capacity and for learning to occur, it requires an active process of filtering, selecting, organizing, and integrating information based upon prior knowledge.

In designing multimedia instructional resources, Mayer (2001) has set out twelve principles for multimedia learning as listed in Table 1.

TABLE 1:

Principles of multimedia learning

\begin{tabular}{|l|l|}
\hline i & Coherence Principle \\
\hline ii & Signaling Principle \\
\hline iii & Redundancy Principle \\
\hline iv & Spatial Contiguity Principle \\
\hline v & Temporal Contiguity Principle \\
\hline vi & Segmenting Principle \\
\hline vii & Pre-Training Principle \\
\hline viii & Modality Principle \\
\hline ix & Multimedia Principle \\
\hline x & Personalization Principle \\
\hline xi & Voice Principle \\
\hline xii & Image Principle \\
\hline
\end{tabular}

Coherence Principle states that it easier for the students to learn if the instructors exclude extraneous materials. They should include only text, graphics and descriptions that support learning goals. Signaling Principle states that it is easier for the students to learn if they are able to identify cues that highlight the salient materials. Thus instructors are recommended to add arrows and other highlighting methods in the resources. Redundancy principles state that it is easier for the students to learn if the information is delivered in a combination of graphics and spoken words than from graphics, narration and written text. Thus, when presenting narration, it should be combined with either graphics or written text, but not combining narration with both graphics and written text. Besides, the use of written text should also be minimized.

Spatial Contiguity Principle refers to the way of organizing words and pictures on the page or screen. It is easier for the students to learn better when corresponding words and pictures are presented near rather than far from each other. Temporal Contiguity Principle refers to the way words and pictures are presented. It is easier for the students to understand when corresponding words and pictures are delivered concurrently rather than successively. Segmenting Principle states that students learn better when they could control the speed of the lesson. Therefore when instructors design multimedia resources, they should design 
functions which allow students to control the pace of the presentation. Besides, breaking long materials into a few shorter segments is also very helpful to the students.

Pre-Training Principle states that it is easier for the students to learn from a multimedia lesson when they know the names and characteristics of the main concepts. In other words, this principle proposes that students should be equipped with necessary prior knowledge before they start a multimedia lesson. Modality Principle states that students learn better from pictures and spoken words than from pictures and written words. Multimedia Principle refers to the act of combining words and pictures in the presentation because it is more effective for the students to learn when there are both words and pictures than from words alone.

Personalization Principle states that students learn better from multimedia lessons when the explanation is in conversational style rather than formal style. Voice Principle states that it is easier for the students to learn when the explanation in multimedia lessons is delivered in a friendly human voice rather than a machine voice. Image Principle mentioned that the speaker's image should not be shown to the students because it is not contributing to student learning.

This theory and its principles provide direction on how to design effective multimedia presentations such as an app for learning.

\section{The Design of app for learning Economics Terminologies}

The objective of this paper is to present the conceptual design of a mobile app for learning Economics terminologies. This app is designed for the secondary school students in Malaysia.

\section{Method}

In developing a mobile app for learning Economics terminologies, the ADDIE model is proposed. ADDIE is an instructional model that guides teachers, instructional designers or any content developer to create an efficient and effective teaching design. ADDIE is the acronym that refers to the stages in the process of creating the instructional design, which are Analysis, Design, Development, Implementation, and Evaluation (Aldoobie, 2015).

\section{Analysis Stage}

In the analysis stage, the designer identifies the learning problem, the instructional goals and objectives, the users' needs, learner's existing knowledge and any other relevant characteristics. As for an app for learning Economics terminologies, the aim is to support classroom learning where students can use the app for self-learning to learn and revise the meaning of Economics terminologies. It functions like a walking dictionary. Due to its ubiquitous nature, students can use it anywhere and anytime they prefer. The content of the app will be prepared in Bahasa Melayu, the language that is used in classroom learning.

\section{Design Stage}

The design stage deals with learning objectives, content, subject matter analysis, lesson planning, assessment instruments, exercises, detailed storyboards, look and feel, graphic design, user-interface and media selection. For this proposed app, the learning objective is for students to understand and able to remember the meanings of Economics terminologies. 
The design process of the app will begin with preparing the content of the app where the list of economics terminologies and their meanings that will be included in the app will be identified. At this stage, a qualitative study will be employed, where an interview will be conducted with the Economics teachers who are the content experts of the subjects. They are required to suggest the list of the economics terminologies which are fundamentals for the secondary school students in Malaysia. In addition to that, the interview will also explore the methods of effectively delivering the meaning of those terminologies. The definition of each Economics terminology will be compiled from the textbook and other references.

Then, graphic design will be created. The app will be divided into three main sections which are 'Tentang Kami' (About us), 'Istilah-istilah Ekonomi' (Economics Terminologies), and 'Uji Minda' (Test your Understanding). The suggested design of the homepage is presented in Figure 1.

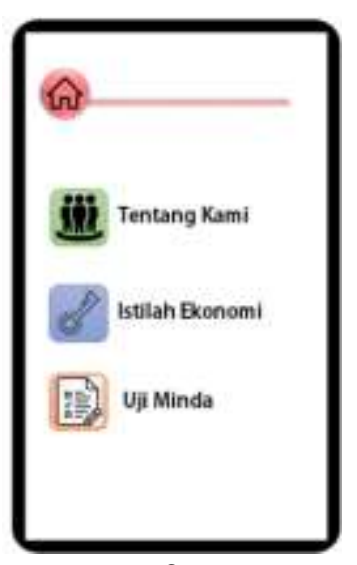

Figure 1: Sample of the app homepage

'Tentang Kami' (About us) section gives a brief introduction of the app, 'Istilah-istilah Ekonomi' (Economics Terminologies) section will show the list of economics terminologies. This list will be organized according to alphabetical order. The selection of the Economics terminology can also be done by using the search button where users can write the terminology that they are looking for. Figure 2 shows the design of this page.

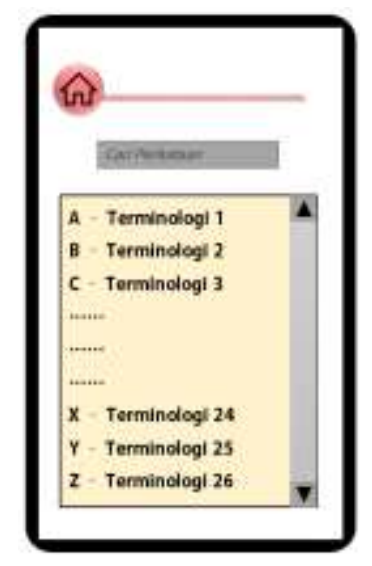

Figure 2: Sample page for List of Economics Terminologies 
Each terminology will be hyperlinked to three different features, namely, 'Definisi' (Definition), 'Huraian' (Elaboration of the meaning) and 'Video' (audio-visual presentation). These features combine text, audio and visual as suggested by the cognitive theory of multimedia learning. 'Definisi' (Definition) and 'Huraian' (Elaboration of the meaning) will deliver the information in the form of written text and graphic, while audio-visual will present the information in video with the verbal explanation. Thus students will have two alternatives, read or listen to the explanation. These two features also function as a rehearsal tool where students will repeat the information in their memories when they watch the video after they read the text or vice versa.

The meaning of economics terminologies will be elaborated with examples and/or represented with graphs and pictorial representation where necessary. All these cognitive elements will help in transferring the information to long term memory (Solso et al., 2008). Figure 3 shows the features of the page - 'Definisi' (Definition), 'Huraian' (Elaboration of the meaning) and 'Video' (audio-visual presentation).

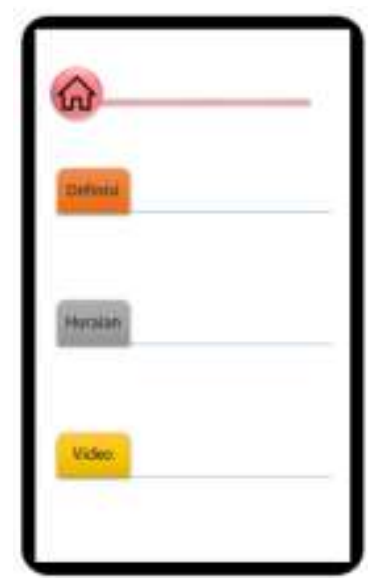

Figure 3: Features of the page - Definition, Elaboration and Video.

'Uji Minda' (Test your Understanding) segment is a segment that contains questions to assess students' knowledge about economics terminologies, for example, multiple-choice questions or matching questions. Assessment is a very powerful teaching and learning aid which does not only assess students' learning but also improves information retention and enhances students' learning (Cheng, 2014). This section also acts as rehearsal tools where information will be repeated in the users' minds when they answer the questions.

The presentation of information in the app will follow the principles stated in the cognitive theory of multimedia learning and embed the cognitive elements as suggested by the theory of information processing.

\section{Development Stage}

The mobile app development stage refers to the process of making application software. Through the usage of mobile apps, the users are provided with various features that will enable them to fulfill all their needs and much more. (Bakhta, 2017).The developers will choose the suitable platform, the coding method, and development techniques to produce 
the intended output. This proposed app will be developed for self-learning purposes by using Android Studio. It will produce a stand-alone version of the application, which is android application package.

\section{Implementation Stage}

The implementation stage is the stage where the design is put into practice with the actual learners (Muslimin et al., 2017). At this stage, the prototype app will be distributed to users, who are the secondary students. They will be trained to explore and use the app.

\section{Evaluation Stage}

The evaluation stage is the stage where the effectiveness of the app will be evaluated. It can be done through heuristics evaluation and usability evaluation methods. With heuristic evaluation, evaluator looks at the user interface and identifies usability problems. On the other hand, usability evaluation involves actual users (Lauesen and Musgrove, 2007). It can be done by using survey questionnaire where at the end of the implementation stage, the questionnaires will be distributed to the students. For example, Muslimin et al. (2017) and Wang (2017) adopted Likert scale questionnaire and open-ended questions to assess students' thoughts and attitudes toward the application.

\section{Conclusion}

This paper presents a conceptual design of Economics mobile app for learning economics terminologies. The app is designed based on cognitive learning theories, namely information processing theory and cognitive theory of multimedia learning. It focuses on ubiquitous selflearning to support classroom learnings of secondary school students in Malaysia. Later, with this app, students can use their smartphones or tablets to study Economics terminologies anytime and anywhere they like. It is hoped that this app will improve knowledge and understanding of economics terminologies which later increase economics literacy.

\section{Acknowledgement}

This project is supported by the Research University Grant, Tier 1, from Universiti Teknologi Malaysia. (Ref. No: PY/2017/00524 \& Cost center no: Q.K130000.2540.16H71).

\section{References}

[Retrieved on 1 September 2019].

Aggarwal, R. (2017), Economics of E-Learning in Higher Education: The Indian Case, Prabandhan: Indian Journal of Management, Vol.10 (6): 40 - 48.

Ahmad, M. \& Shahid, S. (2015). Design and evaluation of mobile learning applications for autistic children in Pakistan. Lecture Notes in Computer Science, LNCS-9296 (Part I), 436-444.

Aldoobie, N. (2015). ADDIE Model, American International Journal of Contemporary Research, $5(6), 68-72$.

Backhouse, R.E. (2012). Economics is a serious and difficult subject, Journal of Economic Methodology, 9(3), 231- 241.

Baddeley, A. D. (1986). Working Memory. Oxford, England: Oxford University Press. 
Bakhta, Kishore (2017). Mobile Application Development: All the Steps and Guidelines for Successful Creation of Mobile App: Case Study, International Journal of Computer Science and Mobile Computing, 6(9), 15-20

Blerkom, V. D. L. (2009). College Study Skills: Becoming a Strategic Learner, 6th Ed., Boston: Wadsworth-Cengage.

Camilleri, A., \& Camilleri, M. A. (2019). Mobile Learning via Educational Apps: An Interpretative Study. In 5th International Conference on Education and Training Technologies (ICETT 2019). Seoul, South Korea.

Chan, M. Y., Segura, G. C. M., \& García, M. G. (2017). Educational mobile application for selflearning the Mayan language, International Advanced Research Journal in Science, Engineering and Technology, 4(12), 57-61.

Cheng, C. K. (2014). Effect of Multiple-Choice Testing on Memory Retention - Cue-Target Symmetry, PhD Dissertation, University of Toronto.

Cheong, C., Bruno, V. \& Cheong, F. (2012). Designing a mobile-app-based collaborative learning system, Journal of Information Technology Education Innovations in Practice, 11, 97-119.

Cochran, J. H. H., Velikova, M. V., Childs, B. D., Simmons, L. L. (2015). Apps for Economics, The Journal of Economic Education, 46(2): 231-232.

Daud, S. M., \& Abas, H. (2013). 'Dyslexia Baca'Mobile App--The Learning Ecosystem for Dyslexic Children. 2013 International Conference on Advanced Computer Science Applications and Technologies, 412-416.

Deng, Q. \& Trainin, G. (2015). Learning vocabulary with apps: From theory to practice, The Nebraska Educator: A Student-Led Journal, 29, 49-69.

Eggen, P., \& Kauchak, D. (2013). Educational Psychology: Windows on Classrooms, 9th ed., Upper Saddle River, NJ: Pearson Education.

Hao, Y., Lee, K. S., Chen, S. T., Sim, S. C. (2019). An evaluative study of a mobile application for middle school students struggling with English vocabulary learning, Computers in Human Behavior, 95, 208-216.

Herodotou, C., Aristeidou, M., Sharples, M., and Scanlon, E. (2018). Designing citizen science tools for learning: lessons learnt from the iterative development of nQuire, Research and Practice in Technology Enhanced Learning, 13:4.

https://econprofaj.wordpress.com/2013/03/26/economic-literacy-is-essential-forall/

https://www.researchgate.net/publication/299653539 [Retrieved on 15 September 2019].

Inayati, R., Handayani, S., Kusandi, J., Haryono, A., Wahyono, H., and Sapir. (2019). The Analysis of the Difficulty in Learning Economics Subject Experienced By Students of Favored State Senior High Schools in City of Malang, KnE Social Science, The First International Conference on Economics and Businesss, pp 195-210.

Johnson, A. (2013). Economic Literacy Is Essential for All.

Jou, M., Lin, Y., \& Tsai, H. (2016). Mobile APP for motivation to learning: an engineering case, Interactive Learning Environments, 24(8), 2048-2057.

Kearney, M., Schuck, S., Burden, K. \& Aubusson, P. (2012). Viewing mobile learning from pedagogical perspective, Research in Learning Technology, 20(1).

Kelley, M. J., and Clausen-Grace, N. (2010). Guiding students through expository text with text feature walks. The Reading Teacher, 64: 191-195. 
Kelly, D. P. (2016). What Do We Know about Khan Academy? A Review of the Literature and Justification for Further Study,

Kuimova, M., Burleigh, D., Uzunboylu, H., \& Bazhenov, R. (2018). Positive effects of mobile learning on foreign language learning, TEM Journal, 7(4), 837-841.

Lauesen, S., and Musgrove, M. P. (2007). User Interface Design - A Software Engineering Perspective, Addison-Wesley.

Li, K. C., Lee, L. Y., Wong, S. L., Yau, I. S. \& Wong, B. T. (2018). Effects of mobile apps for nursing students: learning motivation, social interaction and study performance, The Journal of Open, Distance and e-Learning, 33(2), 99-114.

Mayer, R. E. (2014). Cognitive theory of multimedia learning. In Mayer, R.E (Ed.), The Cambridge Handbook of Multimedia Learning (pp. 43-71). New York, NY, US: Cambridge University Press.

Mayer, R. E., Heiser J., Lonn, S. (2001). Cognitive constraints on multimedia learning: when presenting more material results in less understanding. Journal of Educational Psychology, 93(1), 187-198.

Muslimin, M. S., Nordin, N. M., Mansor, A. Z. and Yunus, M. M. (2017). The design and development of MobiEko: A mobile educational app for Microeconomics module, Malaysian Journal of Learning and Instruction: Special Issues, 221-255.

Salemi, M. K. (2005). Teaching Economic Literacy: Why, What and How, International Review of Economics Education, 4(2): 46-57.

Sierra, J. S., \& Togores, J. S. (2012). Designing mobile apps for visually impaired and blind users. The Fifth International Conference on Advances in Computer-Human Interactions, 47-52.

Slavin, R. E. (2019). Educational Psychology: Theory and Practice. 12th Edition, New Jersey: Pearson Education Inc.

Solso, R. L., MacLin, O. H., and MacLin, M. K. (2008). Cognitive Psychology. 8th Ed. USA: Pearson.

Stathopoulou, A., Karabatzaki, Z., Tsiros, D., Katsantoni, S., \& Drigas, A. (2019). Mobile apps the educational solution for autistic students in secondary education, International Journal of Interactive Mobile Technologies, 13(2), 89-101.

Sung, Y. T., Chang, K. E., and Liu, T. C. (2016). The effects of integrating mobile devices with teaching and learning on students' learning performance: A meta-analysis and research synthesis, Computers \& Education, 94, $252-275$.

Sweller, J. (1994). Cognitive load theory, learning difficulty, and instructional design. Learning and Instruction, 4: 295- 312.

Tay, B. (2013). Elaboration and organization strategies used by prospective class teachers while studying social studies education text-book, Eurasian Journal of Educational Research, 51, 229-252.

Varum, C., Santos, E., and Afreixo, V., (2014). Recent trends and new evidence in economics literacy among adults, Journal of Economics and Economic Education Research, Vol. 15 (2): $187-206$.

Wang, B. (2017). Designing mobile apps for English vocabulary learning, International Journal of Information and Education Technology, 7(4), 279 - 283.

Woolfolk, A. (2013). Educational Psychology. $12^{\text {th }}$ ed., Boston: Allyn and Bacon. 